\title{
MENINGKATKAN MINAT DAN HASIL BELAJAR MATERI AKHLAK TERCELA MENGGUNAKAN MODEL MAKE A MATCH
}

\author{
Imam Choiril Muttaqin \\ SMKN 1 Sedayu Bantul \\ imamuttaqin@yahoo.co.id
}

\begin{abstract}
Through the making a match cooperative learning model with complementary by multimedia devices students are able to make their own knowledge, find steps in finding learning materials that must be mastered by students, both individuals and individuals paired with groups. Thus, this class action research obtained the following conclusions; 1) The application of cooperative learning with a model of making a match can increase students' learning interest in disgraceful moral material, with the results of learning values of $86.21 \%$;2) From the observations there was an increase in learning outcomes, it is evident seen in the assessment of average class learning outcomes in the first cycle is 79.50, is the result of learning above the KKM (minimal completeness criteria), but there are still those who have not reached the KKM of 10 students $(33,33 \%)$. Meanwhile, the value obtained from the average class learning in the second cycle is 84.31 , and all students have reached the KKM (100.00\%).
\end{abstract}

Keywords: minat dan hasil belajar, model make a match, akhlak tercela.

\section{Pendahuluan}

Proses belajar mengajar pasti melibatkan dua komponen penting, yakni guru dan peserta didik. Di samping dua komponen tersebut, proses pembelajaran juga melibatkan komponen lain yang tidak kalah pentingnya, yaitu; tujuan, bahan, metode, media yang tersedia, alat evaluasi dan suasana evaluasi. Satu di antara komponen penting 
dalam proses pembelajaran adalah guru. Karena sesungguhnya gurulah yang melakukan kegiatan-kegiatan untuk menanamkan, membina, dan mengembangkan sistem nilai-nilai kepada peserta didik.

Diterangkan oleh Muhibbin Syah (2006: 223) bahwa Guru sebagai pendidik merupakan faktor penentu kesuksesan setiap usaha pendidikan. Itulah sebabnya setiap pembicaraan mengenai pembaruan kurikulum, pengadaan alat-alat belajar sampai pada kriteria sumber daya manusia yang dihasilkan oleh usaha pendidikan, selalu bermuara pada guru. Hal ini menunjukkan signifikansi posisi guru dalam dunia pendidikan.

Sejalan dengan hal itu, Pendidikan Agama Islam yang biasa disingkat dengan PAI memiliki posisi yang strategis dalam pengembangan sumber daya manusia di bidang keagamaan-spiritual, dalam hal ini peserta didik merupakan aset negeri ini. Harapan tersebut dapat tercapai apabila proses pembelajaran dapat dilaksanakan dengan antusiasme atau minat yang tinggi dari peserta didik dalam mengikuti pembelajaran PAI.

Beberapa kendala pembelajaran yang terjadi di SMKN 1 Sedayu Kabupaten Bantul:

1. Pada waktu proses pembelajaran berlangsung masih ada beberapa peserta didik yang terus menerus mengobrol, yang memainkan alat komunikasi, tidur-tiduran, dan kurang perhatian terhadap pembelajaran yang sedang berlangsung. Dengan kata lain, minat belajar peserta didik dalam pembelajaran PAI masih rendah dikarenakan peserta didik kurang terlibat dalam proses pembelajaran. Model pembelajaran masih terfokus pada guru belum terfokus kepada peserta didik (student centered learning).

2. Masih rendahnya hasil belajar peserta didik dua tahun sebelumnya pada kompetensi dasar aspek akhlak tercela, khususnya materi yang menggabungkan Akhlaq dengan ayat-ayat Al-Quran.

Melihat keadaan di atas, penulis terdorong untuk mengetahui lebih jauh, bagaimana hasil belajar mereka. Untuk mencapai hasil yang maksimal penulis mencoba memberikan pembelajaran dengan model make a match. Atas dasar di atas penulis berpendapat bahwa lemahnya hasil belajar pada mata pelajaran PAI antara lain disebabkan 
lemahnya minat dalam pembelajaran PAI, dan lemahnya minat dapat disebabkan oleh lemahnya strategi/model dan alat pembelajaran yang dipilih oleh guru selama ini.

\section{Landasan Teori}

Hasil belajar peserta didik masih sangat dipengaruhi oleh faktor yang datangnya dari luar diri peserta didik, yang disebut dengan lingkungan. Salah satu lingkungan belajar yang paling dominan mempengaruhi hasil belajar di sekolah adalah kualitas pengajaran yang dikelola oleh guru. Berawal dari sinilah, maka seorang guru dituntut memiliki kemampuan yang cukup untuk merencanakan, mengelola dan mengatur proses pembelajaran dalam kelasnya. Sebagai inisiator guru hendaknya mampu memilih dan mengembangkan bahan pembelajaran yang sesuai dengan dengan tujuan yang hendak dicapai . Di samping itu guru juga harus mampu mengkaji strategi atau metode pembelajaran dan berlatih mengembangkannya sehingga sesuai dan tepat bagi peserta didiknya. Dengan demikian, maka hasil belajar di sekolah sangat dipengaruhi oleh kapasitas peserta didik dan kualitas pembelajaran.

Peranan guru adalah membantu agar setiap peserta didik mampu menemukan keterkaitan antara pengalaman baru dengan pengalaman sebelumnya. Oleh karenanya perlu adanya suasana pembelajaran yang inovatif dan menarik agar minat peserta didik dapat meningkat sehingga hasil belajarnya akan lebih maksimal.

Secara Operasional, Model belajar make a match dikembangkan oleh Lorna Curran tahun 1994. Model ini sering juga disebut model mencari pasangan. Dalam teorinya model ini merupakan suatu pembelajaran yang melibatkan orang lain dalam menyelesaikan persoalan, sehingga hal ini bagian dari sistem pengajaran cooperative learning. Adapun langkah-langkah yang dapat dilakukan dalam penerapan Model belajar make a match adalah sebagai berikut:

1. Guru memberikan menjelaskan apa yang harus dilakukan peserta didik.

2. Guru menyiapkan beberapa kartu yang berisi beberapa konsep atau topik yang cocok, sebaiknya satu bagian kartu soal dan 
bagian lainnya kartu jawaban.

3. Setiap peserta didik mendapat satu buah kartu.

4. Setiap peserta didik memikirkan jawaban soal dari kartu yang dipegang.

5. Setiap peserta didik mencari pasangan yang mempunyai kartu yang cocok dengan kartunya.

6. Setiap peserta didik yang dapat mencocokan kartunya sebelum batas waktu diberi apresiasi.

7. Masing-masing pasangan yang telah cocok mempresentasikan hasil, sementara yang lainnya memberikan komentar. Sementara peserta yang berhasil dengan pasangannya diberi tepuk tangan atau pujian lainnya.

8. Guru dan peserta didik mengambil kesimpulan

9. Guru merefleksi dengan memberikan penegasan konsep materi sebagai bahan penguatan.

10. Penutup.

\section{Prosedur Penelitian}

Pelaksanaan penelitian ini menggunakan rancangan Penelitian Tindakan Kelas. Peneliti akan mengambil dua siklus. Tiap siklus terdiri dari 4 tahap (Kemmis and Tagart, 1988), yaitu (1) Perencanaan, (2) Pelaksanaan tindakan, (3) Observasi (pengamatan), (4) Refleksi.

Tindakan yang dilakukan pada setiap siklus ditentukan atas dasar hasil belajar, masukan dari observer, dan temuan dari siklus sebelumnya. Rencana tindakan yang dilakukan pada setiap siklus dapat diperkirakan secara garis besar seperti berikut ini :

\section{Refleksi Awal/SIKLUS I}

Sebelum mulai penelitian ini, peneliti terlebih dahulu melakukan refleksi awal. Pada tahap refleksi awal ini peneliti melakukan identifikasi kesulitan peserta didik dalam proses pembelajaran Bab 12 dengan tema materi menjaga martabat manusia dengan menjauhi pergaulan bebas dan zina. Dimana dalam materi ini, selain mengangkat aspek akhlak tercela juga terdapat aspek Al-Quran. Setelah dilakukan identifikasi kesulitan peserta didik dalam proses pembelajaran, 
dilanjutkan dengan tahapan-tahapan sebagai berikut:

a. Planning: Dalam tahap ini menyiapkan silabus, RPP, tugas individual, kuis, lembar observasi atau instrumen, penyiapan materi dan alat evaluasi.

b. Acting: melaksanakan pembelajaran sesuai dengan SK dan KD. Adapun langkah-langkah dalam pembelajaran kooperatif model make a match yang akan peneliti lakukan dalam proses pembelajaran adalah sebagai berikut:

1) Peneliti memberikan penjelasan tentang tujuan pembelajaran dan garis besar materi yang akan dibahas.

2) Peneliti memaparkan dan mendiskusikan materi yang dibahas sekaligus memberikan soal permulaan (pre-test).

3) Peneliti menjelaskan kepada peserta didik tentang pembelajaran kooperatif model make a match berikut segala komponen-komponennya.

4) Peneliti menjelaskan apa yang harus dilakukan oleh peserta didik.

5) Peneliti menyiapkan beberapa kartu yang berisi konsep atau topik yang cocok dengan materi, satu bagian kartu soal dan bagian lainnya kartu jawaban.

6) Setiap peserta didik mendapatkan satu buah kartu.

7) Setiap peserta didik memikirkan jawaban/pasangan yang cocok dari kartu yang dipegang.

8) Setiap peserta didik mencari pasangan yang cocok dengan kartu yang sedang dipegangnya.

9) Setiap peserta didik yang dapat mencocokan kartunya sebelum batas waktu diberikan apresiasi.

10) Masing-masing pasangan yang telah cocok mempesentasikan hasil, sementara yang lainnya memberikan komentar. Sementara peserta yang berhasil dengan pasangannya diberi tepuk tangan atau pujian lainnya.

11) Peneliti dan peserta didik mengambil kesimpulan.

12) Peneliti merefleksi dengan memberikan penegasan konsep materi sebagai bahan penguatan.

13) Peneliti memberikan kuis atau soal (post-test) untuk 
mengetahui penguasaan konsep yang dipelajari secara individual.

14) Penutup

c. Observasi: mencatat permasalahan yang ditemukan, mencatat hasil yang dicapai selama pelaksanaan pembelajaran ini.Self Reflecting: mendiskusikan permasalahan dengan teman sejawat dan observer.

d. Menentukan tindakan yang harus dilakukan pada kegiatan berikutnya. Dalam rangka untuk lebih mengoptimalkan pelaksanaan pembelajaran kooperatif ini, maka fasilitator harus benar-benar matang dalam menganalisis faktor penghambat atau kendala dalam siklus I untuk diupayakan solusi terbaik pada siklus II. Apabila penghambat atau kendala tersebut sudah ditemukan solusinya, maka diharapkan hasil belajar pada siklus II akan menjadi lebih baik dari siklus I.

\section{Tahap Lanjutan/SIKLUS II}

a. Planning: Dalam tahap ini dilakukan identifikasi dan penentuan alternatif pemecahan masalah dan pengembangan program tindakan lanjutan/kedua.

b. Acting: Melaksanakan tindakan kedua dengan tahapan;

Peneliti memberikan penjelasan tentang tujuan pembelajaran dan garis besar materi yang akan dibahas sebagai lanjutan dari siklus sebelumnya.

1) Peneliti memaparkan materi dengan tindakan yang lebih spesifik untuk memecahkan permasalahan di siklus sebelumnya sekaligus memberikan soal permulaan (pre-test).

2) Peneliti menjelaskan kepada peserta didik tentang pembelajaran kooperatif model make a match pada siklus ke 2 dengan sedikit modifikasi dari tindakan siklus 1 .

3) Peneliti menjelaskan apa yang harus dilakukan oleh peserta didik.

4) Peneliti menyiapkan beberapa kartu yang berisi potonganpotongan ayat Al-Qur'an yang terbagi dalam jumlah yang banyak dan di akhir pertemuan wajib dihafalkan oleh peserta didik. 
5) Setiap peserta didik mendapatkan satu buah kartu.

6) Setiap peserta didik memikirkan sambungan yang lengkap dari potongan ayat yang sedang dipegang.

7) Setiap peserta didik mencari kelompok ayat yang sesuai dengan potongan ayat.

8) Setiap peserta didik selanjutnya berkelompok/berkumpul berdasarkan ayat yang telah utuh dari potongan-potongan kartu yang dipegang masing-masing, apabila telah menemukan kelompok yang utuh dan benar.

9) Kelompok yang telah berkumpul dan menemukan pasangan yang cocok menjadi bunyi utuh satu ayat, diberikan penghargaan berupa piala untuk menghargai kerja kerasnya.

10) Masing-masing pasangan/kelompok ayat yang telah sempurna mempresentasikan hasil, sementara yang lainnya memberikan penilaian atau komentar. Sementara peserta yang berhasil dengan pasangannya diberi tepuk tangan atau pujian lainnya.

11) Peneliti dan peserta didik mengambil kesimpulan.

12) Peneliti merefleksi dengan memberikan penegasan konsep materi sebagai bahan penguatan dengan menampilkan materi dengan multimedia dan power point.

13) Peneliti memberikan kuis atau soal (post-test) untuk mengetahui penguasaan konsep yang dipelajari secara individual.

14) Penutup.

c. Observasi: Pada tahap ini dilakukan pengumpulan data dan analisis data tindakan kedua.

d. Self Reflecting: Melakukan evaluasi dari tindakan kedua.

Pelaksanaan Penelitian Pembelajaran Kooperatif Model Make a Match dan Inovasi Pembelajaran

1. Siklus I

Sebelum proses pembelajaran dimulai, peneliti terlebih dahulu melakukan upaya untuk mengetahui atau mengukur kemampuan awal yang dimiliki oleh peserta didik dengan melakukan tes awal 
atau pre-test. Hal ini sangat penting untuk dilakukan, mengingat bahwa pendidikan adalah sebuah proses, dan proses itu dikatakan berhasil apabila mampu membawa perubahan ke arah yang lebih baik dari kondisi sebelumnya. Adapun hasil pre-test dalam siklus I adalah sebagai berikut: (Daftar nilai terlampir)

Tabel 1. Hasil Pre Test Siklus I

\begin{tabular}{|c|c|c|}
\hline Nilai & Jumlah Peserta Didik & Prosentase \\
\hline $95-100$ & 0 & 0 \\
$90-94$ & 1 & 3,33 \\
$85-89$ & 10 & 33,33 \\
$80-84$ & 4 & 13,33 \\
$75-79$ & 1 & 3,33 \\
$70-74$ & 10 & 33,33 \\
$65-69$ & 1 & 3,33 \\
$60-64$ & 2 & 6,67 \\
$55-59$ & 0 & 0 \\
$50-54$ & 0 & 0 \\
$45-49$ & 0 & 0 \\
$40-44$ & 0 & 0 \\
$35-39$ & 0 & 0 \\
$30-34$ & 0 & 0 \\
$25-29$ & 1 & 3,33 \\
\hline Jumlah & 30 & 100 \\
\hline
\end{tabular}

Tabel di atas memperlihatkan bahwa hasil pre-test dalam siklus I hasilnya adalah sejumlah 1 peserta didik memperoleh nilai tertinggi dengan rentang 90-94 (3,33\%), sebanyak 10 peserta didik memperoleh nilai rentang antara $85-89(33,33 \%)$, sebanyak 4 peserta didik memperoleh nilai $80-84(13,33 \%)$, sebanyak 1 peserta didik memperoleh nilai rentang 75-79 (3,33\%), sebanyak 10 peserta didik mendapat nilai 70-74 (33,33\%), sebanyak 1 peserta didik memperoleh nilai $65-69(3,33 \%)$, sebanyak 2 peserta didik memperoleh nilai 60-64 $(6,67 \%)$ dan 1 peserta didik memperoleh nilai paling rendah dengan rentang nilai $25-29(3,33 \%)$.

Responden Penelitian yang berjumlah 30 peserta didik setelah pre-test siklus I dilakukan terlihat bahwa 16 peserta didik telah tuntas/ kompeten $(53,33 \%)$ dengan penetapan KKM sebesar 71, sedangkan 
14 peserta didik (46,67\%) dari 30 peserta didik, hasilnya masih belum tuntas atau di bawah KKM.

Berdasarkan pre-test yang dilakukan peneliti, dapat diperoleh jumlah nilai rata-rata kelas pada siklus I adalah $74,83 \%$ dengan nilai tertinggi 90 (1 peserta didik) dan nilai terendahnya adalah 25 (1 peserta didik) sebagaimana telah dipaparkan pada tabel I diatas.

Pada pertemuan selanjutnya masih di Siklus I, proses pembelajaran Pendidikan Agama Islam menggunakan pembelajaran kooperatif model Make a Match dengan memasangkan masing-masing kartu yang cocok dan telah disediakan sebelumnya. Penggunaan model ini dalam pertemuan lanjutan, diharapkan akan dapat meningkatkan hasil belajar peserta didik.

Tabel berikut ini memaparkan hasil belajar peserta didik berupa post-test yang dilakukan pada pertemuan terakhir Siklus I, setelah diterapkan model pembelajaran model make a match. (Daftar nilai terlampir)

Tabel 2. Hasil Post Test Siklus I

\begin{tabular}{|c|c|c|}
\hline Nilai & Jumlah Peserta Didik & Prosentase \\
\hline $95-100$ & 3 & 10,00 \\
$90-94$ & 3 & 10,00 \\
$85-89$ & 10 & 33,33 \\
$80-84$ & 4 & 13,33 \\
$75-79$ & 0 & 0 \\
$70-74$ & 9 & 30,00 \\
$65-69$ & 0 & 0 \\
$60-64$ & 0 & 0 \\
$55-59$ & 0 & 0 \\
$50-54$ & 0 & 0 \\
$45-49$ & 0 & 0 \\
$40-44$ & 0 & 0 \\
$35-39$ & 0 & 0 \\
$30-34$ & 1 & 3,33 \\
$25-29$ & 0 & 0 \\
\hline Jumlah & 30 & 100 \\
\hline
\end{tabular}

Hasil post-test siklus Imemperlihatkan ada peningkatan ketuntasan klasikal hasil belajar peserta didik dibandingkan hasil pre-test diawal 
siklus I walaupun belum maksimal. Hasil post-test dalam siklus I adalah sejumlah 3 peserta didik memperoleh nilai tertinggi dengan rentang 95-100 (10,00\%), sebanyak 3 peserta didik memperoleh nilai rentang antara 90-94 (10,00\%), sebanyak 10 peserta didik memperoleh nilai 85$89(33,33 \%)$, sebanyak 4 peserta didik memperoleh nilai rentang 80-84 (13,33\%), sebanyak 9 peserta didik mendapat nilai 70-74 (30,00\%) dan 1 peserta didik memperoleh nilai paling rendah dengan rentang nilai 30-34 (3,33\%).

Setelah post-test siklus I dilakukan terlihat bahwa 20 peserta didik telah tuntas/kompeten (66,67\%) dengan penetapan KKM sebesar 71, sedangkan 10 peserta didik (33,33\%) dari 30 peserta didik, hasilnya masih belum tuntas atau di bawah KKM. Berdasarkan post-test yang dilakukan peneliti pada siklus I, dapat diperoleh jumlah nilai rata-rata kelas pada siklus I adalah 79,50\% dengan nilai tertinggi 95 (3 peserta didik) dan nilai terendahnya adalah 30 (1 peserta didik) sebagaimana telah dipaparkan pada tabel II diatas.

Dengan demikian terdapat peningkatan hasil belajar peserta didik pada siklus I ini antara sebelum dilakukan tindakan dengan setelah dilakukan tindakan. Hal tersebut tercermin dari peningkatan nilai rata-rata kelasnya meningkat dari sebelumnya 74,83\% menjadi 79,50\%, juga pada nilai tertinggi dan terendahnya, sebelumnya tertinggi 90 dan nilai terendahnya adalah 25 menjadi nilai ggertinggi 95 dan nilai terendahnya adalah 30 .

Meskipun ada peningkatan antara sebelum tindakan dengan setelah ada tindakan, namun masih terlihat peningkatan yang terjadi belum optimal karena masih banyak peserta didik yang belum mencapai kriteria ketuntasan minimal (KKM) dari KD yang dipelajari, yaitu masih terdapat 10 dari 30 jumlah peserta didik dikelas $X$ TKJA yang nilainya belum mencapai KKM (71).

Berdasarkan hasil tersebut, tindakan lanjutan atau siklus II sangat perlu dilakukan dengan tambahan inovasi pembelajaran supaya materi dapat diserap oleh peserta didik dengan maksimal sehingga nilai hasil belajarnya dapat lebih meningkat. Inovasi yang dimaksud peneliti adalah penguatan materi dan model pembelajaran dengan bantuan multimedia, baik berupa penggunaan perangkat keras 
(seperti; komputer/laptop dan LCD) maupun perangkat lunaknya (seperti; pemanfaatan MS. Power Point interaktif dan video/film-film berdurasi pendek) yang disiapkan sesuai dengan materi ajar.

Kombinasi dari pemanfaatan perangkat multimedia dengan model pembelajaran make a match akan mengajak peserta didik lebih aktif, enjoy dan tetap fokus dan konsentrasi dalam mengikuti proses pembelajaran. Salah satu pendapat tentang manfaat multimedia dikemukakan oleh (Nana Sudjana dan Ahmad Rivai, 1992: 2), diantaranya:

a. Pengajaran akan lebih menarik perhatian peserta didik sehingga dapat menimbulkan motivasi belajar.

b. Bahan pengajaran akan lebih jelas maknanya sehingga dapat lebih dipahami oleh para peserta didik dan memungkinkan peserta didik menguasai tujuan pembelajaran secara lebih baik.

c. Metode mengajar akan lebih bervariasi, tidak semata-mata komunikasi verbal melalui penuturan kata-kata oleh guru, sehingga peserta didik tidak bosan. Guru tidak kehabisan tenaga apalagi bila guru mengajar untuk setiap jam pelajaran.

d. Peserta didik lebih banyak melakukan kegiatan belajar sebab tidak hanya mendengarkan uraian guru, tetapi juga aktifitas lain seperti mengamati, melakukan dan mendemonstrasikan.

Kerucut pengalaman yang dikemukakan oleh Edgar Dale, juga memberikan gambaran bahwa pengalaman belajar yang diperoleh peserta didik dapat melalui proses perbuatan atau mengalami sendiri apa yang dipelajari, proses mengamati dan mendengarkan melalui media tertentu dan proses mendengarkan melalui bahasa. Semakin konkret peserta didik mempelajari bahan pengajaran, contohnya melalui pengalaman langsung, maka semakin banyaklah pengalaman yang diperoleh peserta didik. Sebaliknya, semakin abstrak peserta didik memperoleh pengalaman, contohnya hanya mengandalkan bahasa verbal, maka semakin sedikit pengalaman yang akan diperoleh peserta didik.

Akan tetapi, apabila pembelajaran hanya mengandalkan multimedia saja hanya akan mendorong pembelajaran hanya satu arah, tidak aktif, dan pada akhirnya monoton. Oleh karena itu perlu 
dikombinasikan dengan model make a match yang telah digunakan pada siklus sebelumnya.

Selama proses pembelajaran pada setiap pertemuan kelas di siklus I ini, peneliti diamati aktivitasnya oleh observer, dengan maksud untuk menemukan sisi aktivitas positif dan negatifnya untuk menentukan tindakan pada tahap berikutnya yaitu siklus ke 2. Adapun hasil pengamatan yang dilakukan oleh observer pada siklus I adalah sebagai:

\section{Tabel 3. Rangkuman Aktivitas Guru dalam Kegiatan P embelajaran Siklus I}

\begin{tabular}{|c|c|}
\hline \multicolumn{2}{|l|}{ Aktivitas Guru } \\
\hline Positif & Negatif \\
\hline $\begin{array}{l}\text { 1. Menyampaikan pendahuluan dan pre-test. } \\
\text { 2. Menjajaki pemahaman peserta didik dan } \\
\text { memberikan umpan balik pada peserta } \\
\text { didik yang bertanya dan menjelaskan } \\
\text { materi yang belum jelas. } \\
\text { 3. Memberikan motivasi positif dengan } \\
\text { membangkitkan semangat peserta } \\
\text { didik untuk saling mencari pasangan } \\
\text { yang cocok/benar dari kartu yang telah } \\
\text { tersedia. } \\
\text { 4. Lebih melibatkan aktivitas peserta } \\
\text { didik secara menyeluruh dalam proses } \\
\text { pembelajaran. } \\
\text { Menjelaskan dengan lugas, gamblang, } \\
\text { santai tapi serius, ramah dan dapat } \\
\text { memberikan umpan tawa/humor kepada } \\
\text { peserta didik. }\end{array}$ & 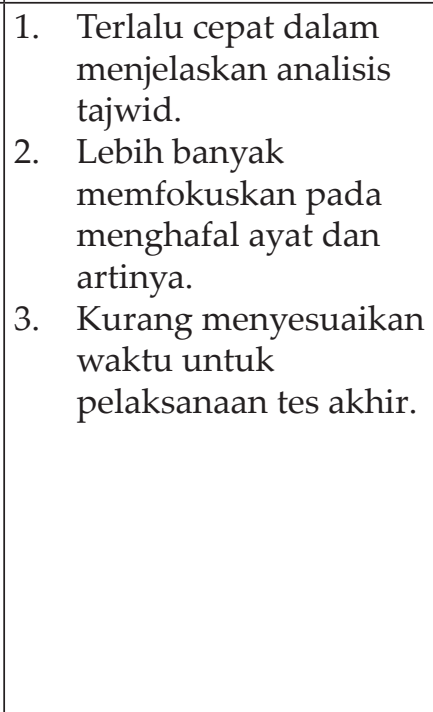 \\
\hline
\end{tabular}

Tabel hasil pengamatan observer pada pertemuan pertama siklus I sebagaimana tersebut di atas, terdapat dua macam aktivitas guru, yaitu aktivitas positif dan negatif. Aktivitas positif adalah sikap yang harus dipertahankan dan dilanjutkan penggunaannya pada siklus II, sedangkan aktifitas negatif adalah sikap yang harus diperbaiki atau ditinggalkan oleh guru pada proses pembelajaran pada siklus II agar suasana dan kualitas pembelajaran semakin meningkat. 


\section{Siklus II}

Pada siklus II ini, selain menggunakan pembelajaran kooperatif model make a match, peneliti memadukanya dengan memanfaatkan perangkat multimedia, hal ini memiliki banyak tujuan diantaranya;

a. Agar dapat menarik perhatian peserta didik sehingga minat belajarnya meningkat,

b. Memperjelas makna dan materi sehingga memudahkan peserta didik memahami dan menguasainya,

c. Hemat energi bagi guru dan multi-komunikasi bagi peserta didik sehingga dapat mengakomodir berbagai gaya belajarnya,

d. Peserta didik lebih aktif dengan berbagai aktifitas seperti mengamati, melakukan dan mendemonstrasikan.

Sebelum dilakukan proses pembelajaran pada siklus II, peneliti terlebih dahulu melakukan pre-test untuk menjajaki kemampuan awal peserta didik sebelum mengikuti proses pembelajaran kooperatif model make a match yang dipadukan dengan perangkat multimedia ini. Adapun hasilnya adalah sebagai berikut: (Daftar nilai terlampir)

Tabel 4. Hasil Pre-test Siklus II

\begin{tabular}{|c|c|c|}
\hline Nilai & Jumlah Peserta Didik & Prosentase \\
\hline $95-100$ & 3 & 10,00 \\
$90-94$ & 3 & 10,00 \\
$85-89$ & 11 & 36,67 \\
$80-84$ & 4 & 13,33 \\
$75-79$ & 3 & 10,00 \\
$70-74$ & 5 & 16,67 \\
$65-69$ & 0 & 0 \\
$60-64$ & 0 & 0 \\
$55-59$ & 0 & 0 \\
$50-54$ & 0 & 0 \\
$45-49$ & 0 & 0 \\
$40-44$ & 0 & 0 \\
$35-39$ & 1 & 3,33 \\
$30-34$ & 0 & 0 \\
$25-29$ & 0 & 0 \\
\hline Jumlah & 30 & 100 \\
\hline
\end{tabular}


Hasil pre-test siklus II ini belum nampak hasil yang diharapkan dari pembelajaran dan masih mempunyai kecenderungan sama dengan hasil belajar siklus satu, terdapat peningkatan namun hanya sedikit sekali terlihat dari tabel diatas hasil pre-test dalam siklus II ini, sejumlah 3 peserta didik memperoleh nilai tertinggi dengan rentang 95-100 (10,00\%), sebanyak 3 peserta didik memperoleh nilai rentang antara 90-94 (10,00\%), sebanyak 11 peserta didik memperoleh nilai 85$89(36,67 \%)$, sebanyak 4 peserta didik memperoleh nilai rentang 80 $84(13,33 \%)$, sebanyak 3 peserta didik mendapat nilai $75-79(10,00 \%)$, sebanyak 5 peserta didik mendapat nilai 70-74 (16,67\%) dan 1 peserta didik memperoleh nilai paling rendah dengan rentang nilai 35-39 (3,33\%).

Setelah pre-test siklus II ini dilakukan terlihat bahwa 24 peserta didik telah tuntas/kompeten (80,00\%) dengan penetapan KKM sebesar 71 , sedangkan 6 peserta didik $(20,00 \%)$ dari 30 peserta didik, hasilnya masih belum tuntas atau di bawah KKM.

Berdasarkan pre-test yang dilakukan peneliti pada siklus II, dapat diperoleh data awal berupa jumlah nilai rata-rata kelasnya adalah 80,83\% dengan nilai tertinggi 100 (1 peserta didik) dan nilai terendahnya adalah 35 (1 peserta didik) sebagaimana telah dipaparkan pada tabel IV diatas.

Untuk mendapatkan umpan balik dan masukan dari observer, maka pada siklus II ini juga masih dilakukan pengamatan oleh observer selama proses pembelajaran berjalan. Adapun hasil pengamatan tersebut adalah sebagai berikut:

Tabel 5. Rangkuman Aktivitas Guru dalam Kegiatan Pembelajaran Pertama Siklus II

\begin{tabular}{|c|c|}
\hline \multicolumn{2}{|c|}{ Aktivitas Guru } \\
\hline Positif & Negatif \\
\hline $\begin{array}{l}\text { 1. Menyampaikan pendahuluan } \\
\text { dengan mengaitkan materi } \\
\text { pembelajaran yang lalu dan pre- } \\
\text { test. }\end{array}$ & $\begin{array}{l}\text { 1. Ada } 2 \text { peserta didik } \\
\text { yang masih bermain } \\
\text { dengan HP, tidak fokus } \\
\text { ke pelajaran karena }\end{array}$ \\
\hline
\end{tabular}




\begin{tabular}{|l|l|}
\hline \multicolumn{2}{|c|}{ Aktivitas Guru } \\
\hline \multicolumn{1}{|c|}{ Positif } & \multicolumn{1}{c|}{ Negatif } \\
\hline 2. Memperkaya pendalaman materi & $\begin{array}{l}\text { mungkin posisinya } \\
\text { dengan menggunakan perangkat } \\
\text { bultimedia berupa Ms. Power } \\
\text { belakang dan tidak } \\
\text { Point yang komunikatif dan video } \\
\text { pembelajaran yang menyentuh } \\
\text { hati/perasaan peserta didik. }\end{array}$ \\
$\begin{array}{l}\text { 3. Suasana kondusif. } \\
\text { 4. Komunikatif. }\end{array}$ & \\
\hline
\end{tabular}

Dari tabel di atas dapat terlihat bahwa ada dua kategori aktivitas guru, yaitu aktivitas guru yang dinilai positif oleh observer dan yang dinilai negatif oleh observer. Aktivitas guru yang dikategorikan sebagai aktivitas positif artinya sangat bagus untuk dipertahankan dan tetap dilaksakan dalam proses pembelajaran berikutnya. Sedangkan kategori aktivitas guru yang negatif berarti sikap tersebut harus ditinggalkan atau diperbaiki pada proses pembelajaran berikutnya.

Sebelum dilakukan evaluasi hasil belajar atau post-test, peneliti terlebih dahulu mencari informasi tentang tanggapan peserta didik terhadap penggunaan pembelajaran kooperatif model Make a Match untuk diterapkan dalam materi Akhlaq Tercela pada semester 2 ini. Hal ini dilakukan supaya peneliti dapat mengetahui bagaimana minat dan antusiasme peserta didik dalam mengikuti pembelajaran.

Peneliti menggunakan angket untuk mengetahui minat dan tanggapan peserta didik terhadap penggunaan pembelajaran kooperatif dalam proses pembelajaran. Hasil angket respon peserta didik terhadap penggunaan pembelajaran kooperatif adalah sebagai berikut: 
Tabel 6. Tanggapan Peserta Didik terhadap Proses Pembelajaran Kooperatif Model Make A Match

\begin{tabular}{|c|c|c|c|}
\hline No & Pernyataan & Jumlah & Alasan \\
\hline 1 & Sangat Menarik & 25 & 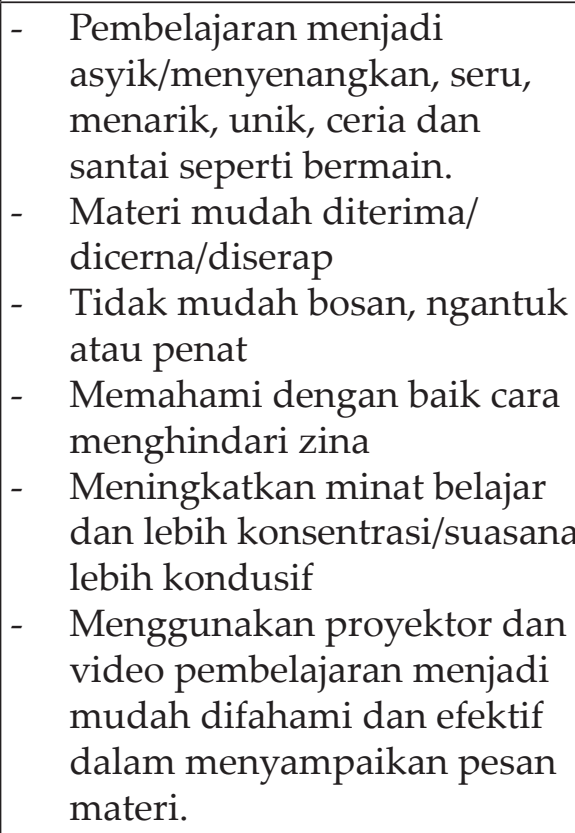 \\
\hline 2 & Cukup Menarik & 4 & 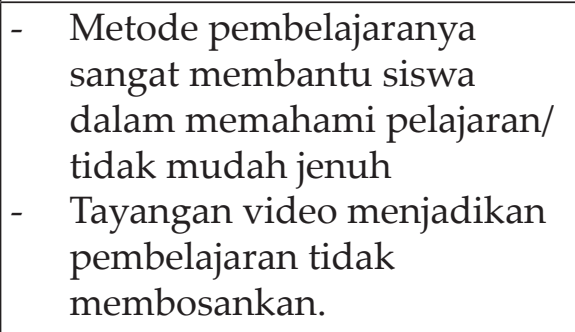 \\
\hline 3 & Kurang Menarik & - & ----- \\
\hline 4 & Tidak Menarik & - & ---- \\
\hline & Jumlah & 29 & \\
\hline
\end{tabular}

Keterangan: 1 peserta didik atas nama Ryan Hendra Saputra no. absen 27 tidak memberikan tanggapan karena saat pertemuan terakhir di siklus 2 ijin tidak masuk sekolah dikarenakan sakit, termasuk juga tidak mengikuti post-test. 
Tabel tersebut menyajikan data mengenai minat, antusiasme dan tanggapan peserta didik dalam mengikuti pembelajaran PAI dengan menggunakan model make a match, hasilnya adalah 25 peserta didik menyatakan sangat menarik dengan angka prosentase sebesar 86,21 \%, 4 peserta didik menyatakan cukup menarik dengan angka persentase sebesar $13,79 \%$. Selebihnya sebesar 3,33\% tidak dihitung karena satu peserta didik tidak masuk sekolah karena sakit saat dilakukan pengisian angket.

Dalam tahap pelaksanaan siklus II ini peneliti sudah melakukan tindakan dari hasil self-reflecting pada siklus I, yaitu dengan lebih memberikan tugas kepada peserta didik untuk menghafal ayat-ayat terkait materi menjaga martabat manusia dengan menjauhi pergaulan bebas dan zina di rumah masing-masing. Kemudian saat pertemuan berikutnya akan diminta oleh guru untuk mendemonstrasikan hafalan satu persatu di depan kelas dengan disimak guru. Hal ini ditegaskan guru saat mengakhiri siklus I, dan menjadi modal utama dalam siklus II yang lebih banyak membahas ayat-ayat terkait materi.

Setelah melakukan demonstrasi hafalan dan memperkuat materi dengan model kartu berpasangan make a match, lalu dilanjutkan presentasi kelompok kartu yang cocok, maka diakhiri dengan post test siklus II. Adapun hasil dari post-test atau uji kompetensi Bab 12 seperti disajikan dalam tabel berikut:

Tabel 7. Hasil Post Test Siklus II

\begin{tabular}{|c|c|c|}
\hline Nilai & Jumlah Peserta Didik & Prosentase \\
\hline $95-100$ & 6 & 20,69 \\
$90-94$ & 5 & 17,24 \\
$85-89$ & 4 & 13,79 \\
$80-84$ & 5 & 17,24 \\
$75-79$ & 9 & 31,03 \\
$70-74$ & 0 & 0 \\
$65-69$ & 0 & 0 \\
$60-64$ & 0 & 0 \\
$55-59$ & 0 & 0 \\
$50-54$ & 0 & 0 \\
$45-49$ & 0 & 0 \\
$40-44$ & 0 & 0 \\
$35-39$ & 0 & 0 \\
\hline Jumlah & 29 & 100 \\
\hline
\end{tabular}


Tabel di atas memperlihatkan bahwa hasil post test dalam siklus II hasilnya adalah sejumlah 6 peserta didik memperoleh nilai sangat tinggi dengan rentang 95-100 (20,69\%), sebanyak 5 peserta didik memperoleh nilai rentang antara 90-94 (17,24\%), sebanyak 4 peserta didik memperoleh nilai $85-89(13,79 \%)$, sebanyak 5 peserta didik memperoleh nilai rentang $80-84(17,24 \%)$ dan 9 peserta didik memperoleh nilai dengan rentang 75-79 (31,03\%).

Responden penelitian yang berjumlah 29 peserta didik pada pertemuan terakhir di siklus II, setelah post-test dilakukan terlihat bahwa 29 peserta didik telah tuntas/kompeten (100,00\%) dengan penetapan KKM sebesar 71, dengan demikian tidak ada peserta didik yang harus remidi, karena seluruh siswa telah mencapai KKM.

Berdasarkan post-test pada siklus II yang dilakukan peneliti, dapat diperoleh jumlah nilai rata-rata kelas pada siklus II adalah 84,31\% dengan nilai tertinggi 100 ( 2 peserta didik) dan nilai paling rendah 75 sebagaimana telah dipaparkan pada tabel 1 diatas.

Adapun akumulasi nilai pre-test dan hasil belajar pada siklus I dan siklus II dapat dilihat pada tabel berikut ini:

Tabel 8 Akumulasi Nilai Pre Test Dan Post Test (Hasil Belajar) Kelas X Tkj A Pada Siklus I Dan Siklus II

\begin{tabular}{|l|c|c|c|c|}
\hline \multirow{2}{*}{ HASIL TEST } & \multicolumn{4}{|c|}{ NILAI } \\
\cline { 2 - 5 } & \multicolumn{2}{|c|}{ Siklus I } & \multicolumn{2}{c|}{ Siklus II } \\
\cline { 2 - 5 } & Pre Test & $\begin{array}{c}\text { Post Test } \\
\text { (Hasil Belajar) }\end{array}$ & Pre Test & $\begin{array}{c}\text { Post Test } \\
\text { (Hasil Belajar) }\end{array}$ \\
\hline Nilai rata-rata & 74,83 & 79,50 & 80,83 & 84,81 \\
\hline Nilai terendah & 25 & 30 & 35 & 75 \\
\hline Nilai Tertinggi & 90 & 95 & 100 & 100 \\
\hline Tuntas & 16 & 20 & 24 & 29 \\
\hline Belum Tuntas & 14 & 10 & 6 & 0 \\
\hline
\end{tabular}

Tabel di atas terlihat bahwa pada siklus I, nilai rata-rata pre-test dengan hasil belajar terdapat peningkatan nilai sebesar 4,67\%. Sedangkan pada siklus II, nilai rata-rata pre-test dengan hasil belajar terdapat peningkatan nilai sebesar 3,98\%. Adapun peningkatan hasil belajar pada siklus I dan siklus II terdapat peningkatan nilai sebesar 5,31\%. 
Peningkatan nilai juga terjadi pada masing-masing tahap tindakan, yaitu nilai terendah, peningkatan nilai terendah pada siklus I adalah 5 digit angka, peningkatan nilai terendah pada siklus II adalah 40 digit angka, sedangkan peningkatan nilai terendah pada siklus I dengan siklus II adalah 50 digit angka. Sehingga terjadi kenaikan sebesar 50\%.

Peningkatan nilai juga terjadi pada masing-masing tahap tindakan, yaitu nilai tertinggi, peningkatan nilai tertinggi pada siklus I adalah 5 digit angka, pada siklus II nilai tertinggi telah mencapai puncak yaitu 100. sedangkan peningkatan nilai tertinggi pada siklus I dengan siklus II adalah 10 digit angka. Sehingga terjadi kenaikan sebesar 10\%.

Demikian pula peningkatan jumlah peserta didik yang tuntas dengan yang tidak tuntas, pada akhir siklus I yang belum tuntas sejumlah 10 peserta didik sedangkan pada post-test/hasil belajar siklus II yang belum tuntas 0 peserta didik dengan kata lain seluruh peserta didik telah tuntas atau mencapai KKM.

Untuk mengetahui bagaimana minat dan antusiasme peserta didik dalam mengikuti pembelajaran kooperatif model make a match, peneliti juga menyiapkan instrumen observasi perilaku peserta didik yang diamati langsung oleh observer. Jika pada tabel VI merupakan tanggapan langsung dari peserta didik mengungkapkan perasaannya dalam mengikuti pembelajaran, pada tabel berikut disajikan rangkuman hasil pengamatan observer mengenai perilaku peserta didik di kelas saat mengikuti tindakan kelas menggunakan model make a match:

\section{Tabel 9. Rangkuman Hasil Observasi Perilaku Siswa Saat Penerapan Model Make A Match dalam Pembelajaran Materi Akhlak Tercela}

\begin{tabular}{|c|l|c|c|c|c|}
\hline \multirow{2}{*}{ NO } & \multicolumn{1}{|c|}{ ASPEK YANG DIAMATI } & \multicolumn{2}{c|}{ Siklus I } & \multicolumn{2}{c|}{ Siklus II } \\
\cline { 3 - 6 } & Part 1 & Part 2 & Part 1 & Part 2 \\
\hline 1 & $\begin{array}{l}\text { Ada perhatian secara terus menerus } \\
\text { dalam belajar }\end{array}$ & 7 & 8 & 10 & 10 \\
\hline 2 & $\begin{array}{l}\text { Ada rasa suka dan senang } \\
\text { mengikuti pembelajaran }\end{array}$ & 8 & 9 & 10 & 10 \\
\hline 3 & $\begin{array}{l}\text { Tidak berputus asa dan berusaha } \\
\text { dengan cepat mencari pasangannya }\end{array}$ & 7 & 9 & 9 & 9 \\
\hline
\end{tabular}




\begin{tabular}{|c|l|c|c||c|c||}
\hline \multirow{2}{*}{ NO } & \multicolumn{2}{|c|}{ ASPEK YANG DIAMATI } & \multicolumn{2}{c||}{ Siklus I } & \multicolumn{2}{c|}{ Siklus II } \\
\cline { 3 - 6 } & & Part 1 & Part 2 & Part 1 & Part 2 \\
\hline 4 & $\begin{array}{l}\text { Mengikuti pembelajaran dengan } \\
\text { antusias }\end{array}$ & 6 & 7 & 9 & 10 \\
\hline 5 & $\begin{array}{l}\text { Mau mempresentasikan hasil } \\
\text { penemuan dengan pasangannya }\end{array}$ & 8 & 9 & 10 & 10 \\
\hline 6 & $\begin{array}{l}\text { Melaksanakan diskusi dalam } \\
\text { rangka mencari pasangan }\end{array}$ & 7 & 8 & 9 & 10 \\
\hline 7 & $\begin{array}{l}\text { Dimanifestasikan melalui } \\
\text { partisipasi pada aktivitas dan } \\
\text { kegiatan }\end{array}$ & 8 & 8 & 10 & 9 \\
\hline 8 & Masuk kelas tepat waktu & 10 & 10 & 8 & 10 \\
\hline 9 & $\begin{array}{l}\text { Memberikan stimulus positif } \\
\text { kepada teman yang sedang } \\
\text { menyampaikan presentasi }\end{array}$ & 9 & 9 & 9 & 9 \\
\hline 10 & Bangga dan puas setelah belajar & 7 & 8 & 9 & 10 \\
\hline & $\quad$ Jumlah SKOR & 77 & $\mathbf{8 5}$ & $\mathbf{9 3}$ & $\mathbf{9 7}$ \\
\hline
\end{tabular}

Tabel 9 atas terlihat bahwa minat peserta didik dalam mengikuti proses pembelajaran semakin meningkat dengan hasil observasi dari observer di atas. Pada siklus I pertemuan pertama mencapai skor 77 dari 10 aspek yang diamati, kemudian meningkat pada pertemuan kedua dengan skor capaian 85. Bahkan pada siklus II pertemuan pertama meningkat perolehan skornya menjadi 93 dan pada akhir pertemuan di siklus II skor puncak minat peserta didik dalam mengikuti pembelajaran dengan model make a match mencapai skor 97.

Peningkatan yang menaikan skor capaian tersebut mengindikasikan bahwa peserta mempunyai minat yang tinggi terhadap proses pembelajaran yang dilakukan dengan kata lain peserta didik sangat tertarik dan memiliki antusiasme yang tinggi.

\section{Penutup}

Berdasarkan hasil penelitian tindakan kelas ini nampak bahwa melalui pembelajaran kooperatif model make a match dengan teknik perpaduan perangkat multimedia peserta didik mampu membangun sendiri pengetahuan, menemukan langkah-langkah dalam mencari penyelesaian dari suatu materi yang harus dikuasai oleh peserta didik, baik secara individu maupun berpasangan dengan kelompok. 
Dengan demikian maka penelitian tindakan kelas ini diperoleh simpulan sebagai berikut:

1. Penerapan pembelajaran kooperatif dengan model make a match dapat meningkatkan minat belajar peserta didik pada materi akhlak tercela, dengan hasil nilai pengamatan 86,21 \% (kategori sangat menarik).

2. Dari hasil observasi memperlihatkan bahwa terjadi peningkatan hasil belajar, sebagaimana terlihat dalam perolehan nilai hasil belajar rata-rata kelas pada siklus I adalah 79,50, merupakan hasil pembelajaran di atas KKM, akan tetapi masih ada yang belum mencapai KKM sejumlah 10 peserta didik (33,33\%). Sedangkan perolehan nilai hasil belajar rata-rata kelas pada siklus II adalah sebesar 84,31 dan seluruh peserta didik telah mencapai KKM $(100,00 \%)$ sebagaimana terlihat pada tabel VIII.

\section{Daftar Pustaka}

Arif Rohman. 2009. Memahami Pendidikan dan Ilmu Pendidikan. Yogyakarta: Laksbang Mediatama.

Arikunto,Suharsimi,dkk. 2009. Penelitian Tindakan Kelas. Jakarta: Bumi Aksara.

Kemdiknas. 2010. Rambu-RambuPengembangan Kegiatan KKG dan MGMP. Jakarta: Dirjen PMPTK.

Lie, Anita. 2010. Cooperative Learning, Mempraktikkan Cooperative Learning di Ruang-Ruang Kelas. Jakarta: Grasindo.

Mulyasa. 2009. Praktik Penelitian Tindakan Kelas. Bandung: PT Remaja Rosda Karya.

Purwanto, M. Ngalim. 1998. PsikologiPendidikan. Jakarta: Departemen Pendidikan dan Kebudayaan.

Sanjaya, Wina. 2006. Strategi Pembelajaran Berorientasi Standar Proses Pendidikan. Jakarta: Kencana.

Sigit, S. 2005. Pengembangan Modul Pembelajaran Fisika Berbasis Multimedia. Tesis.

Slameto. 2002. Belajar dan faktor-faktor yang mempengaruhinya. Jakarta: Rineka Cipta.

Slavin, Robert E. 2009. Cooperatif Learning. Bandung: Nusa Media. 


\section{e-Tarbawjimam choirl Muttagin}

Soekarno. 2009. Penelitian Tindakan Kelas. Surakarta: Media Perkasa.

Sudjana, Nana \& Ahmad Rivai. 1992. Media Pengajaran. Bandung: Sinar Baru Algensindo.

Sudjana, Nana. 1990. Penilaian Hasil Proses Belajar Mengajar. Bandung: Remaja Rosdakarya.

Syah, Muhibbin. 2008. Psikologi Pendidikan dengan Pendekatan Baru. Bandung: Remaja Rosda Karya.

Undang-Undang Republik Indonesia No. 14 Tahun 2005 Tentang Guru dan Dosen. Bab I Pasal 1 Ayat 1.

Undang-Undang RI No. 20 Tahun 2003 Tentang SISDIKNAS, 2009, Bandung: Citra Umbara.

Uno, Hamzah B. 2008. Orientasi Baru dalam Psikologi Pembelajaran. Jakarta: PT Bumi Aksara.

Wena,Made. 2009. Strategi Pembelajaran Inovatif Kontemporer. Jakarta Timur: PT Bumi Aksara.

Wiriaatmadja, Richiati. 2008. Metode Penelitian Tindakan Kelas. Bandung: PT Remaja Rosda Karya. 